\title{
First experiences in the treatment of juveniles and idiopathic scoliosis with SpineCor braces
}

\author{
A Sarchioto \\ From 9th International Conference on Conservative Management of Spinal Deformities - SOSORT 2012 \\ Annual Meeting \\ Milan, Italy. 10-12 May 2012
}

\section{Background}

The standardized treatment of juvenile, and adolescent, idiopathic scoliosis is accepted everywhere: physiotherapy for curves until $15-20^{\circ} \mathrm{Cobb}$, rigid brace between 20 and $30-35^{\circ} \mathrm{Cobb}$, cast between 30 and $40-45^{\circ} \mathrm{Cobb}$ and surgery over $45^{\circ} \mathrm{Cobb}$.

\section{Aim}

The aim of this work is to verify the efficacy and effectiveness of the SpineCor dynamic brace, in juvenile and adolescent idiopathic scoliosis with curves between 20 and $50^{\circ} \mathrm{Cobb}$.

\section{Methods}

All patients (range of age 5 to 15 years) were treated with a SpineCor dynamic brace. All braces were ordered, fitted and used, following the standard canons of the appropriate procedure. A photographic control was carried out, just after fitting, a clinical control in a month, a clinical and photographic in three months, and a clinical, photographic and radiographic in six months.

\section{Results}

Over $90 \%$ of patients had a very important change in their posture and cosmetic appearance. None of them left the treatment.

\section{Conclusion}

The SpineCor dynamic brace used is efficient and effective. Because it does not limit any movement, and allows practicing all sports, (but swimming), and dance, and since it is virtually invisible under clothing, no patient has complained of the treatment. Both patients and parents were

ASL BN1, Benevento, Italy satisfied. This good result allows, and encourages, us to continue in using this brace.

Published: 3 June 2013

\section{References}

1. Coillard C, Circo A, Rivard CH: A new concept for the non-invasive treatment of Adolescent Idiopathic Scoliosis: the Corrective Movement principle integrated in the SpineCor System. Disabil Rehabil Assist Technol 2008, 3(3):112-119.

2. Vachon V, C C, Zabjek K, Rhalmi S, Rivard C-H: Analyse de survie d'une cohorte de 365 patients scoliotiques traitÃ $\odot$ s par le corset SpineCor Ã. I'HÃ'pital Sainte-Justine; 2006.

doi:10.1186/1748-7161-8-S1-P11

Cite this article as: Sarchioto: First experiences in the treatment of juveniles and idiopathic scoliosis with SpineCor braces. Scoliosis 2013 8(Suppl 1):P11.
Submit your next manuscript to BioMed Central and take full advantage of:

- Convenient online submission

- Thorough peer review

- No space constraints or color figure charges

- Immediate publication on acceptance

- Inclusion in PubMed, CAS, Scopus and Google Scholar

- Research which is freely available for redistribution
() Biomed Central

\section{Biomed Central}

(C) 2013 Sarchioto; licensee BioMed Central Ltd. This is an Open Access article distributed under the terms of the Creative Commons Attribution License (http://creativecommons.org/licenses/by/2.0), which permits unrestricted use, distribution, and reproduction in any medium, provided the original work is properly cited. 